\title{
The Use of Visuals in Issue Framing Signifying Responsible Drinking
}

\author{
Højgaard Christiansen, Lærke
}

Document Version

Accepted author manuscript

Published in:

Organization Studies

DOI:

10.1177/0170840618759814

Publication date:

2018

License

Unspecified

Citation for published version (APA):

Højgaard Christiansen, L. (2018). The Use of Visuals in Issue Framing: Signifying Responsible Drinking.

Organization Studies, 39(5-6), 665-688. https://doi.org/10.1177/0170840618759814

Link to publication in CBS Research Portal

\section{General rights}

Copyright and moral rights for the publications made accessible in the public portal are retained by the authors and/or other copyright owners and it is a condition of accessing publications that users recognise and abide by the legal requirements associated with these rights.

Take down policy

If you believe that this document breaches copyright please contact us (research.lib@cbs.dk) providing details, and we will remove access to the work immediately and investigate your claim. 


\section{The Use of Visuals in Issue Framing: Signifying Responsible Drinking}

\section{Lærke Højgaard Christiansen}

Journal article (Accepted manuscript*)

\section{Please cite this article as:}

Højgaard Christiansen, L. (2018). The Use of Visuals in Issue Framing: Signifying Responsible Drinking.

Organization Studies, 395-6), 665-689. https://doi.org/10.1177/0170840618759814

Copyright () The Author(s) २०18. Reprinted by permission of SAGE Publications.

* This version of the article has been accepted for publication and undergone full peer review but has not been through the copyediting, typesetting, pagination and proofreading process, which may lead to differences between this version and the publisher's final version AKA Version of Record. 


\title{
The use of visuals in issue framing: Signifying responsible drinking
}

\author{
Lærke Højgaard Christiansen* \\ Copenhagen Business School
}

November 30th 2017

* The author would like to thank Markus Höllerer, Dennis Jancsary, Jochem Kroezen, Christine Larson, Sarah Soule, Ursula Plesner, Woody Powell, the editors of this special issue, and three anonymous reviewers for their helpful insights, and comments on previous versions of this paper. A previous version of this paper was presented at the workshop 'giving visual and material form to ideas, identity and imagination' at WU Vienna, May 2014. A part of this research project has been conducted while the Author was a SCANCOR postdoc at Stanford University. 


\title{
The use of visuals in issue framing: Signifying responsible drinking
}

\begin{abstract}
This article offers new insights into the organizational framing of social issues by drawing attention to the use of visual framing. These insights are based on a case study of the organization, Drinkaware, and its visual framing of the issue of alcohol-related harm in its campaign material. The study identifies three overall visual framing functions performed by Drinkaware's campaign material: normalizing alcohol consumption, defining and delimiting the scope of the issue and the responsible parties, and establishing the organization's identity as an expert. The article contributes to institutional theory, and to organizational theory more broadly by elaborating on the significant role of visuals in the framing of an issue, particularly by providing a systematic elaboration of the visual framing functions and components. The article also extends the literature on issues and issue fields, by showing how visuals contribute to defining and delimiting issues and establishing an expert identity in an issue field.
\end{abstract}

\section{Keywords}

Visual framing, social issues, issue fields, collective organizations, expertise, social responsibility, responsible drinking 


\section{Introduction}

Within organization and management theory, visual framing efforts, such as media campaigns, product design, and headquarter architecture, represent an important yet broadly overlooked dimension in organizations' attempts to construct meaning in and around their organizations. A recent line of work (e.g. this special issue; Bell, Warren \& Schroeder, 2014; Meyer, Höllerer, Jancsary \& van Leeuwen, 2013) has brought attention to our limited understanding of the role of visuals, and points to visuals as exceptionally useful means to entice audiences and gain legitimacy. Visuals are widely used by activists and organizations in their framing efforts to evoke strong emotions in their audiences and mobilize support for their political agenda in relation to social issues (i.e. Doerr, Mattoni, \& Teune, 2013; Jasper \& Poulsen, 1995; McLaren, 2013; Snow, Benford, McCammon, Hewitt, \& Fitzgerald, 2014). This work on framing within the social movement literature suggests that visuals increase audience engagement and enhance the legitimacy of the message. Therefore, visuals often play a central role in framing 'the socially situated process of meaning construction' (Cornelissen \& Werner, 2014, p. 183). Visuals and visual framing efforts may thus enhance the effect of organizations' attempts to influence internal and external audiences' understandings of social issues. Still, organizational research exploring how visuals contribute to organizations' framing efforts in relation to a social issue is limited. 
In the social movement literature on framing, researchers have started to explore the role that visuals may play in the mobilization, diffusion, and framing of issues (Doerr et al., 2013; Luhtakallio, 2013; Rodriguez \& Dimitrova, 2011). To advance such insights, researchers are proposing ways in which visuals and visual framing could be analyzed, focusing on identity or mobilization, or explicitly considering frames and framing (Doerr \& Teune, 2012; Luhtakallio, 2013). Currently, however, this literature includes little empirical research that probes into how issues may be framed through the use of visuals (Bell, 2001; Rodriguez \& Dimitrova, 2011). In organizational and institutional theory, scholars have explored framing efforts, contestation, struggles over meaning, and identity work in issue fields (Guérard, Bode \& Gustafsson, 2013; Lefsrud \& Meyer, 2012; Litrico \& David, 2017; Meyer \& Höllerer, 2010). Issue fields are constituted by the various actors engaged with a specific issue, such as corporate environmentalism (Hoffman, 1999). This work on issue fields has primarily focused on field-level contestation, comparing the framing and counter-framing efforts of the various actors. Due to the field level emphasis, this work has primarily focused on the 'content' of different competing frames within an issue field, and has payed less attention to the strategies used by the individual actors within the field. Still, the study by Lefsrud and Meyer (2012) proposed that different verbal rhetorical legitimation strategies may be used to establish expert legitimacy within an issue field. This work does not, however, consider the role that visuals may play in the framing of issues. 
By focusing on a single organization's visual framing efforts in an issue field, it is feasible to study and detail how visuals may contribute to the framing of an issue. Here, I address the following research question: How do visuals contribute to framing an issue and establishing a collective organization as an expert within an issue field? A collective organization can be broadly defined as a type of umbrella or metaorganization with other organizations as members or supporters, set up to tackle an issue of shared concern (Ahrne \& Brunsson, 2005; Campbell, 1989). The empirical focus of this article is on issue-based industry collectives (IBICs), representing a unique form of collective organization; IBICs are founded and supported by an industry and focus exclusively on engaging with a specific social issue (Christiansen \& Kroezen, 2016). Specifically, this article presents a case study of the IBIC Drinkaware, a UKbased independent trust supported by 61 alcohol-industry actors (in 2014), including major producers, retailers, supermarkets, and trade associations (e.g. Diageo, Carlsberg, and Tesco). Generally, organizations rely on a range of different tactics, including campaigning and lobbying, to gain influence within an issue field. Drinkaware qualifies as a critical case (Eisenhardt, 1989) as their sole engagement with the issue of alcoholrelated harm is through their educational campaigns, which employ visually based communication to a significantly high degree. By studying Drinkaware's framing of the issue of alcohol-related harm in its campaigns (which include both visuals and verbal text), this article emphasizes the role that visuals play in the framing of an issue. The 
study is based on an analysis of Drinkaware's campaign materials from 2007-2013 (i.e. poster/print advertising, information material, and a mobile application). The data analysis was multimodal (Kress \& van Leeuwen, 1996), considering the combined stimuli of the campaign material, including both the visual and verbal modes. Still, the role of visuals was the primary focus, as the analysis pertains to 'visual framing' (Goffman, 1974; Luhtakallio, 2013; Rodriguez \& Ditrova, 2011). The findings show how Drinkaware's campaign material performs three overall visual framing functions: normalizing alcohol consumption, defining and delimiting the scope of the issue and the responsible parties, and establishing the organization's identity as an expert.

The study makes three main contributions. First, it contributes to organizational and institutional theory by providing a systematic elaboration of the visual framing functions performed by an organization's campaign material. Second, the study contributes to the literature on issues and issue fields by showing how the issue was defined and delimited in visuals through the 'subject' (specific groups, i.e. excessive drinkers, young people, and parents) and through the use of contrasting (responsible versus irresponsible), moralization, and emotional activation. Third, and relatedly, the study contributes further to the issues literature by illustrating how visual framing contributed to establishing a collective organization's identity as an expert in an issue field. 
The article proceeds as follows: First, a theoretical background for the study is provided. Second, the research context and research design are described, giving an overview of the issue field around alcohol-related harm as the empirical context, and Drinkaware and its campaigns as its visual framing efforts in relation to the issue of alcohol-related harm. Third, the findings from the study are presented, elaborating the role of visuals in issue framing, by specifying the visual framing functions and components. Finally, the article concludes with a discussion of the findings and the theoretical implications of this study for future research.

\section{Theoretical context}

Theories of organizations have not yet fully dealt with the role that visuals play in an organizational context; recently, several calls have been made to pay closer attention to the visual aspect of discourse and meaning (call for this special issue; Bell et al., 2014; Meyer et al., 2013). In the realm of institutional theory, studies on framing have often focused on verbal language (Cornelissen, Durand, Fiss, Lammers \& Vaara, 2015; Jones, Meyer, Jancsary, \& Höllerer, 2017). However, visuals also play an important role in the construction of reality and the formation of public opinion (Gamson, Croteau, Hoynes, \& Sasson, 1992; Gamson \& Modigliani, 1989), and the visual aspect of communication has certain characteristics that may enhance, mitigate, or even override the meaning of a verbal text (Messaris \& Abraham, 2001; Wischmann, 1987). In practice, activists and 
organizational collectives often use visuals in their framing efforts to mobilize support for their political agendas (i.e. Snow et al., 2014) and shape issue fields. Thus, it is important to gain better insights into how visuals contribute to the framing of issues. Below, I outline the theoretical contexts and concepts utilized in this study, namely 'issue fields and social issues', 'framing,' and 'visual framing.'

\section{Issue fields and social issues}

An issue field (Hoffman, 1999) is determined by which actors are engaged, what problems are discussed, how the problems are defined, and what solutions are deemed relevant. The various actors in the issue field make different claims and assertions about what constitutes the issue, what the problem is, who is responsible for its existence, and its solution (Gamson et al., 1992; Gusfield, 1981). Hence, issue fields are generally contested, as there are several actors attempting to construct and shape the meaning of the issue (Edelman, 1988; Gusfield, 1981; Hoffman, 1999). The aim of this article is to study one central collective organization's construction of an issue. To accomplish this, I draw on Gusfield's conceptualization of social issues (ownership and causal and political responsibility) in my analysis of Drinkaware's campaign material.

According to Gusfield (1981), there are three important aspects to consider in relation to the structure of social issues (public problems), 'ownership' and two kinds of 'responsibility'. Actors in an issue field may attempt to gain ownership - 'the ability to 
create and influence the public definition of a problem' (Gusfield, 1981, p. 10). Owners have the legitimacy and authority to make claims and assertions about the issue in question. Furthermore, others look to owners to define and formulate solutions to the social problem/issue. Other groups of actors may attempt to avoid a possible obligation to become involved in solving a specific issue, and thus, they may deliberately attempt to resist claims that the issue is their responsibility (Gusfield, 1981). In relation to responsibility, Gusfield (1981) distinguishes between 'causal' and 'political' responsibility. The first focuses on the causal aspect of the issue: Why does this issue exist? The latter is a matter of policy: What should be done about the issue and who should do it? Gusfield's concepts overlap partly with Snow and Benford's (1988, 2000) 'diagnostic framing' (causal) and 'prognostic framing' (political). However, I find that Gusfield's concepts are more clearly centered on actors (e.g. parents, consumers, politicians, and firms) playing a role in relation to a particular issue, both in relation to causing and/or solving it, which is a key element in Drinkaware's construction of the issue in its campaigns. The aspect of 'ownership' is also particularly useful in relation to this study, as Drinkaware's campaign efforts contribute to establishing Drinkaware as an expert in the issue field and potentially gaining some form of 'ownership' of the issue of alcohol-related harm. Researchers have proposed various rhetorical legitimation strategies (verbal), which may be used to establish expert legitimacy, such as authorization (through association with law or official authority), rationalization (by 
proclaiming objectivity and utilization), moralization (through reference to specific value systems), or normalization (through claims of normalcy) (Höllerer, Jancsary, Meyer, \& Vettori, 2013; Lefsrud \& Meyer, 2012; Suddaby \& Greenwood, 2005). Jones et al. (2017) recently suggested that any visual efforts to establish legitimacy might rely on similar strategies.

\section{Framing}

The concept of framing has been defined and used in many ways and in different literatures (Benford and Snow, 2000; Cornelissen and Werner, 2014). Frames are packages of proposals and critiques that highlight certain aspects of a specific issue, thereby representing a socially constructed guide to interpretation (Goffman, 1974; Jasper and Poulsen, 1995). In the present article, the term 'framing' is used to describe the socially situated process of meaning construction (Cornelissen and Werner, 2014), with a focus on the specific function of framing efforts. Framing efforts have a performative and transformative role, as they are intended to mobilize potential activists and shape institutional fields, or in this case, issue fields (Snow \& Benford, 1988; Snow et al., 1986).

In an issue field, there are always several actors attempting to frame the meaning of the issue (Edelman, 1988; Gusfield, 1981; Hoffman, 1999; Meyer \& Höllerer, 2010). Consequently, the subject of contestation has been a common theme in several studies. 
Meyer and Höllerer (2010) show that different ways of framing an issue are closely related to specific local cultural and sociopolitical contexts (shareholder value in Austria). Moreover, Lefsrud and Meyer (2012) explore professionals' discursive (verbal) construction of climate change, focusing specifically on the framings and identity work performed by various actors in the issue field. They emphasize how actors attempt to frame themselves as experts to attain a favorable position in the issue field and gain influence. In this context, it is important to note that work on framing tends to focus on frames as 'content' or 'strategies' (Benford and Snow, 2000). The work on framing contests outline different 'frames' or framings,' and thus, they primarily address the 'content' of various competing frames. Here, the focus is on 'strategies', more specifically on the function of the visual framing efforts of one organization (albeit a collective organization).

\section{Visual framing}

Work on visuals has suggested that visuals are particularly well suited for framing; not only can they obscure issues, but they may also appear factual (Rodriguez \& Dimitrova, 2011; Wischmann, 1987). According to Meyer et al. (2013), this is due to the specific way visuals construct reality; they appear as iconic representations of reality rather than framed versions of it. While work on visual framing is still in its infancy, some social movement scholars have focused on the visual expression of social movements and 
have begun to address the role that visuals may play in mobilization and diffusion (Doerr et al., 2013; Luhtakallio, 2013; Rodriguez \& Dimitrova, 2011). Some theoretical progress has been made, such as Doerr and Teune's (2012) proposed model for visual analysis of social movements; this recommends a focus on different forms of expression - that is, of the body, object, image, and graphic design - in relation to framing, identity, or mobilization. Few studies have been performed, however, one paper by Luhtakallio (2013) provides a visual frame analysis of activists' contention representations on their websites in Finland and France, offering one methodological approach to studying visual material — in this case, photos. In communication and media studies, it has also been suggested that visual framing is crucial when it comes to managing key audiences' impressions, gaining legitimacy, and securing competitive positioning (Meyer et al., 2013). This suggests that visuals may also play an important role in issue framing. Work within this area is rare, but in a recent study, Lefsrud, Graves, \& Phillips (2018) analyze a broad range of media ads created by different opponents in the contested issue fields around the Alberta oil sands. Their study shows how actors in the field combine visuals and verbal text in their legitimation struggles to promote or undermine the oil sands industry. Still, we need more work that explores visual framing and its specific underlying functions. Here, I systematically explore how visuals may contribute to the framing of an issue and establishing a collective organization's identity as an expert within an issue field. 


\section{Research context and design}

In this study, I explore how the issue of alcohol-related harm was constructed by the IBIC, Drinkaware. First, I elaborate on the research context and the significance of the issue of alcohol-related harm. Following this, I outline my research design and methods.

\section{Research context: The issue of alcohol-related harm and Drinkaware}

As of the mid-1990s, a new public health movement had emerged; it was centered on the promotion of preventive measures to fight existing and developing health threats in order to improve populations' quality of life. ${ }^{1}$ This movement brought with it an increased focus on the health challenges posed by alcohol consumption (Goldstein, Goon and Yach, 1995; Tulchinsky and Varavikova, 2010), the concern about which has peaked over the last 10 to 15 years. Figure 1 provides an illustration of this development. Drawing on the Newsbank database, this figure shows the keyword pairing of 'health' and 'alcohol' in articles from five top UK newspapers between 2000 and 2013. During this time, the pairing of these words increased threefold.

Insert Figure 1 around here.

In tandem with this movement, different actors in the alcohol industry have also started to engage with this issue in the context of individual company actions and industry 
associations, as well as in supporting, funding, and partnering with non-profit organizations focused explicitly on the issue of alcohol-related harm (Christiansen \& Kroezen, 2016; Christiansen \& Lounsbury, 2013). Since the 1980s, the number of IBICs dealing with the issue of alcohol-related harm has increased. Today, more than 30 such organizations operate across 27 countries (Babor \& Robaina, 2013; World Wide Brewing Alliance, 2014).

The IBIC, Drinkaware, is an independent trust based in the UK that deals with the issue of alcohol-related harm. Drinkaware was set up as a trust in 2007 following a memorandum of understanding between the industry and the government. Drinkaware was to fulfil the educational campaigning role envisaged in the government's 'Alcohol Harm Reduction Strategy' (of 2004) for a fund voluntarily financed by the alcohol industry (producers and retailers) to tackle the issue of alcohol-related harm. The original aim was to:

1. Increase awareness of:

- Why and how to drink safely and responsibly; and

- The impact of alcohol misuse on society and on the health and wellbeing of individuals, their families and communities.

2. Improve attitudes towards:

- Motivation and personal responsibility to drink safely and responsibly; and

- The unacceptability of binge drinking and drink related disorder.

3. Effect positive changes in behaviour related to alcohol consumption [sic, emphasis in original].

(Drinkaware, 2007, para. 2) 
In 2014, Drinkaware had 61 funders $^{2}$ who had donated $£ 5.5$ million. The organization has a staff consisting of 18 employees, an independent board of trustees, and a medical advisory board. The members of the board of trustees have a range of different backgrounds from civil society, health, and the alcohol industry. The medical panel is in place to provide qualified advice that guides the organization's campaigns. The large network of supporters enables Drinkaware to undertake new and innovative campaign initiatives (e.g. packaging information and the mobile application). Drinkaware's campaigns have a substantial reach, especially considering that all funders' products carry a health warning label referring to Drinkaware's website. The inclusion of the label is voluntary, but it is recommended by the UK government as good practice. The site is also prominent in all partners' communication materials (i.e. print advertisements, websites, packaging, etc.), which amounts to around 3 billion marketing pieces annually (Cooper, 2010). The Drinkaware website provides consumers with information or 'facts about alcohol', and in 2012, 4.1 million people visited the site; in 2014, that number had more than doubled, reaching 8.4 million visitors.

Since its founding in 2007, Drinkaware has become a central figure in the issuebased field around alcohol-related harm. The organization has achieved primacy, as it is one of the most salient UK organizations focused on this issue and has received government support from the start. With a mandate from the Department of Health, 
Drinkaware initiated the national campaign, 'Why let the good times go bad?', which ran from 2009 to 2013. At the time, the campaign was the largest national campaign targeting excessive drinking among young people aged 18-24 years. It was shown in half of all phone booths, pubs, bars, supermarkets, and other alcohol retail stores. Drinkaware's framing of the issue has gained traction and increasing support in the UK alcohol industry. This is particularly evident in terms of the increase in the number of supporters (retailers and producers) from 45 to 60 between 2009 and 2014 during the run of the 'Why let the good times go bad?' campaign. Today, the organization enjoys support from 107 donors.

Drinkaware is an extreme case (Eisenhardt, 1989), as educational campaigns represent the central means by which it engages with the issue field; in fact, it is explicitly restrained from engaging in policy lobbying. Thus, visuals are especially significant in Drinkaware's framing of the issue of alcohol-related harm, and the case has provided me with a unique insight into how visuals contribute to the framing of an issue and establishing a collective organization as an expert in an issue field.

\section{Data collection}

This article presents findings from an inductive case study. The analysis focuses on campaign materials from 2007 to 2013, totaling 52 pieces of campaign material (e.g. print and online material, mobile applications, and collaborative campaigns with 
industry actors), in the range of $3-15$ pieces per year. An overview of the data sources is provided in Table 1. For this study, I selected all the Drinkaware campaign material available on the drinksinitiatives.eu website (in 2014), which collects and shares responsible drinking programs supported by European spirits producers. This material was supplemented by the 2013 campaign material available on Drinkaware's website at the time, and additional data were retrieved directly from Drinkaware upon request (from 2011-2013). While the analysis does not include all Drinkaware's campaign material from 2007-2013, the three different sources were used to secure a relatively comprehensive sample. I limited the analysis to print/web-based campaign materials consisting of visuals, including both visual and verbal elements (i.e. figures/shapes, photos, and verbal text). Videos were excluded for practical reasons.

Insert Table 1 around here.

While the analysis focused on Drinkaware's campaign material (visuals), additional data on Drinkaware, the UK alcohol industry, and the issue field were also collected. These data, which included annual reports, website content, press releases, organizational and campaign reviews, and six interviews with key actors in the UK alcohol industry, were used as background information to contextualize Drinkaware and its campaigns. In addition, I drew on my knowledge from previous and ongoing 
research on the international alcohol industry (i.e. Christiansen and Kroezen, 2017; Christiansen and Lounsbury, 2013).

\section{Analytical procedures}

I created an analytical framework that made it possible to analyze a larger set of visual materials with a qualitative emphasis, as it builds on ideas from visual frame analysis (e.g. Doerr et al., 2013; Luhtakallio, 2013) and recent work in the field of organizational studies (Höllerer et al., 2013; Jancsary, Höllerer \& Meyer, 2015). Therefore, when analyzing the campaign material, I adopted the assumption that framing involves specific constructions of the issue and packages of proposals and critiques that are aligned to emphasize specific aspects of the issue. In my analysis, I drew on the literature on social movements and framing (Goffman, 1974; Jasper \& Poulsen, 1995; Snow \& Benford, 2000), and to identify the visual framing of the issue in the campaign material, I used ideas and concepts from social semiotics (Kress \& van Leeuwen, 1996), decoding advertisements (Williamson, 1978), and rhetoric, in the form of Aristotle's classic modes of argument (Aristotle, 1984). The modes were used to study how the campaign material visually constructs the issue through the use of logical reasoning $(\log o s)$, persuasion via emotions (pathos), and by establishing a credible source (ethos).

In my analysis, I carried out the following three steps, as outlined and defined in Table 2. In step 1, the campaign pieces were analyzed as multimodal texts. Like 
advertisements, the individual pieces are composite visuals - that is, visuals that combine verbal, visual, and graphic elements (i.e. special fonts, shapes, and colors). Hence, they are multimodal, as their meaning is realized via several semiotic codes (Kress and van Leeuwen, 1996). I treated the different parts (verbal and visual elements) as interactive and affecting one another, working as elements of an integrated text (Kress and van Leeuwen, 1996). Still, the central element in the analysis focused on the specific role of the visual dimension in each of the campaign pieces (see the appendix). In step 2, I coded the campaign materials individually according to their rhetorical construction of the issue of alcohol-related harm (Gusfield, 1981). In doing so, I asked the following empirical questions: What is alcohol? What is the role of alcohol in society? What is the proposed problem/solution? Who are the central actors (the subjects and responsible parties)? I used ideas from rhetoric when studying the constructed modes of arguments and appeal, ethos, pathos, and logos (Aristotle, 1984). To understand how the meaning of the issue was constructed in the campaigns, appeal was further analyzed using Williamson's (1978) concepts (derived from semiology) of 'subject appellation,' 'differentiation', 'absence,' and the identified 'condensing symbols' (Jasper and Paulsen, 1995). In step 3, I performed coding across the campaign pieces and compared them, exploring general themes and the various visual framing functions. All steps were carried out manually. 
Insert Table 2

\section{Findings}

Based on the findings from the case study, in this section, I elaborate the role of visuals in framing the issue of alcohol-related harm. Table 3 provides an overall summary of the visual framing of the issue found in the analysis, including examples from the data; visual examples are given in Figure 2. I identified six themes constituted in the campaigns that comprised contextualized sets of argumentative resources, as follows: alcohol as normal, excessive drinking problem, youth problem, parenting problem, consistent association with signs of 'truth and science', and performing the role of educator. These were grouped into the three overall framing functions of the campaign material: normalizing alcohol consumption, defining and delimiting the issue and responsible parties; and establishing identity as an expert. The presentation of the findings is structured around these framing functions, which are also outlined in Table 4. This table summarizes the findings and a conceptualization of the visual framing components.

Insert Table 3, Table 4 and Figure 2 


\section{Normalizing alcohol consumption}

The main rhetoric evident in all the campaign pieces upholds the idea of alcohol consumption as being an aspect of socializing - a natural element in a normal life. This sense of 'normalcy' is signified in photos by the invocation of tradition and social occasions at which alcohol is often consumed, such as at parties, during Christmas, or when relaxing and unwinding on the couch. Photos depict 'normal' people, rather than models, and the homes and neighborhoods shown are consistent with average, middleclass homes. Hence, as depicted in the visuals, the framing of alcohol consumption begins with the signal that the consumption of alcohol is normal (ethos) on specifically defined occasions. The campaign pieces do not condemn alcohol consumption in general, but only a certain aspect of it—irresponsible drinking.

Overall, the main rhetoric is that alcohol consumption is normal, but there is also an effort to construct a contrast between responsible and irresponsible drinking. The campaign pieces construct a reality in which alcohol consumption is a normal part of socializing (even for young adults). Irresponsible drinking, however, is not considered socially acceptable behavior, as depicted via both the visual and verbal elements. Still, most of the campaign visuals do not provide a clear distinction between responsible and irresponsible behaviors, and the subject (the reader of the image) must 
deduce what irresponsible drinking may be. The component of contrasting is a central one; it is key to Drinkaware's framing and delimiting of the issue, as well as its construction of responsibility. The aspect of contrasting will be elaborated further in the following sections.

\section{Defining and delimiting the scope of the issue and the responsible parties}

Here, the focus is on how causal and political responsibility are constructed through the campaigns, and particularly, the distinctive role that visuals play. A central aspect of the visual framing is the subject and subject appellation, as 'A sign replaces something for someone. It can only mean if it has someone to mean to' (Williamson, 1978, p. 40). All signs in the campaign material depend on the individual as subject, interpreter, and meaning giver for the campaign pieces. The subject (receiver of the message) is created as a specific type of subject (i.e. responsible/irresponsible parent) by the message in the campaign piece (Williamson, 1978). Via subject appellation, individuals (i.e. excessive drinkers, young people, and parents) are called upon to identify with the message. Next, I move deeper into how visual framing in the campaigns delimits the scope of the problem, as it is defined as an excessive drinking, youth, or parenting problem, respectively.

The excessive drinking problem. Many of the campaign materials define the issue of alcohol-related harm as being a problem of excessive drinking. The campaigns 
target the consumers - the excessive drinkers - as the responsible parties. The campaigns focus on occasions on which excessive drinking is commonly understood to occur and/or 'tools' that may be used by consumers to avoid intoxication before and while consuming alcohol, that is, water, food, and the 'Why let the good times go bad?' mobile application. Excessive drinking is symbolized through visual cues, such as the presence of many bottles, empty or half-empty glasses, and people who are either sick or sleeping in awkward positions or places (e.g. in a bathtub or next to a toilet bowl), signifying that the people have passed out from drinking too much. The tool-focused materials feature bottles or glasses of water, soft drinks, food, and even a 'wingman' (usually a friend that provides support to a man in the process of approaching women), whose responsibility is to ensure that intoxication does not ruin one's chances with possible partners.

There is a contrast made between being in or outside a group due to excessive drinking. Thus, the campaigns signal social disapproval and exclusion as the immediate consequences of excessive drinking. An alternative reading of at least one of the pictures could also be that passing out carries with it an implicit status, as one picture portrays a young man passed out in a bathtub and two young women who are taking pictures and 'laughing at him' (see the Youth Drinking examples in Figure 2).

The campaigns are moralizing and appeal to emotions. They are often humorous and framed more as advice or friendly guidance (ethos). Several of the social occasions 
that are represented appeal to emotions (pathos) by drawing on the image of good times worth remembering that would be undermined by excessive drinking, which would leave the subject feeling sick and/or excluded from the fun (e.g. being laughed at rather than laughing with the others).

The youth problem. In the materials, excessive drinking and the youth problem overlap on many occasions. Still, this framing constructs and delimits the issue as a distinct youth problem. The campaigns directly target young people, conveying the message that the problem should be resolved by consumers, in this case, young individuals. The youth-problem framing is marked by signs such as young people that have passed out, are sick, or have been left alone. The campaigns fit the 'world' of a young audience and its priorities. Each campaign piece has a composition (of pictures, verbal texts, and graphics) that seems to level with young receivers and speak their language (verbal and visually), rather than speaking to them through logical reasoning alone (logos). The language and pictures used are informal, for instance, 'Play it smooth with a break from the booze' (Drinkaware, 2010; ethos). In addition, the people and situations (laughing, giggling, and having fun) are illustrated in pictures that would be expected to resonate with the subject, who is likely to identify with these people and situations. Several of the campaign pieces are brightly colored and convey a 'feel-good spirit'. A friendship aspect is also signified in several pieces. 
One campaign series explicitly focuses on contrast, emphasizing the distinction between having a 'good time' and getting sick (for example, see Figure 2). This is signified by two pictures of the same young person in similar settings (i.e. at a party or a night club). In one picture, the person is smiling and socializing with other people; in the other, the same person is portrayed as being sick and acting in a way that would most likely be perceived as embarrassing. Alternatively, the person is depicted as being alone on a bathroom floor or at home. The contrast situations are separated by the outline of either a wine glass or a bottle, signifying the contrast between being responsible and being irresponsible.

Moralizing and emotional appeal are also significant in the campaigns addressing youth drinking. An emotional appeal (pathos) is made, as the youth drinking definition clearly distinguishes between social success and failure, feeling good versus sick, success versus failure with the opposite sex, and being a good friend versus being a bad or annoying one. The fear of being excluded from a community (due to too much drinking) is likely to be especially salient among young people. A smaller component of the 2009 version of 'Why let the good times go bad?' draws on 'men's locker-room humor,' humor that involves crude, sexual, and perhaps even sexist topics (overlapping with excessive drinking; see the example in Figure 2). In one example, the danger of drinking excessively is illustrated in terms of a picture of beer googles paired with verbal text signifying that the beer googles increase one's risk of 'pulling a moose,' 
which is slang for pairing with an unattractive woman. Together, the (verbal) guidelines and the strong pictures showing these contrasting situations also appeal to the mode of reason $(\log o s)$.

The parenting problem. This framing of the problem stands out because the target subjects are not the young consumers of the product, but rather their parents (e.g. in the 'Talk now and avoid problems later' campaign, 2013). The issue is constructed as a problem that may be caused by parents, and thus, something that should also be solved by them (causal and political responsibility). The parenting problem is marked by visual signs, such as parents and adults drinking in front of children, children and parents together in different contexts, and black and dark colors, representing serious problems or death. The campaign pieces either directly state (in longer materials, e.g. several-page information booklets) or signify (in one-shot pieces, e.g. posters or onepage print ads in magazines) that recommendations are based on research and facts, thereby increasing the credibility of the message. Visually, this is also supported by figures, tables, and charts in the parents' guidebook. The appeal to logic (logos) again draws on research and science, stating that parents' actions (or inaction) have been proven to have the greatest effect on young people, thereby suggesting that ensuring children's and young people's appropriate behavior related to alcohol consumption is primarily a parental responsibility. 
The contrasts in this framing of the issue as a parenting problem are more subtle, playing on good versus bad parenting and a right and wrong way to teach one's children about alcohol. The depiction of parents drinking does not necessarily signify bad parenting, as parents are depicted as negligent or unaware that their children are observing them. In these photos, parents are not looking in the direction of the children. Thus, it can be inferred that there is a right (and wrong) way to teach children about alcohol.

Moralizing and emotional appeal are salient in the parenting-problem framing. This is evident in the contrasts between right and wrong, described above, as well as when verbal campaign text suggests (ethos) that parents talking to their children about alcohol is just as essential as their talking to them about sex, using phrases like, 'Time for that talk about the bars and the beers' (see Figure 2), reformulating the phrase 'the birds and the bees,' connoting the hesitance that is often associated with talking to one's children about human reproduction. Meanwhile, this also suggests that drinking alcohol is just as normal (institutionalized) and natural a part of human life as having sex (the overall framing of alcohol consumption as normal). The emotional appeal (pathos) is quite strong, as evidenced in the use of dark colors, the mention of A\&E (accident and emergency department at a hospital), and the tagline, 'Talk now and avoid problems later. Go to drinkaware.co.uk.' These elements all serve to reinforce the message that parental inaction will harm children, as without guidance, children could end up in the 
emergency room or experience other types of serious trouble. Furthermore, there is also a latent emotional appeal that centers on the subject (parent) as still being needed and remaining an important person in the child's/teenager's life.

\section{Establishing identity as an expert}

A crucial step in the framing of the issue is establishing and legitimating the identity of the sender, Drinkaware, as an expert. An organization needs to be perceived as a credible source of information and education (ethos) and gain some form of ownership of the issue to shape the field (Gusfield, 1981). In part, Drinkaware's identity as an expert is established in the campaign material via the two previously described functions. In addition, Drinkaware's identity is established with the 'consistent association with signs of "truth and science"" and Drinkaware "performing the role of educator'; these aspects are elaborated below.

Consistent association with signs of 'truth and science'. In the campaign materials, I identified several signs that pointed toward (connoted) the central 'referent systems' (Williamson, 1978) of truth/science. A referent system is a system of meaning to which a sign refers, such as a wedding ring, which connotes the referent system of marriage. Drinkaware's consistent association with the 'facts' (e.g. information charts, government recommendation signs, 'Go to Drinkaware for the facts about alcohol') -

connoting the referent system of truth/science-results in the establishment of a 
connection that becomes what Williamson (1978) refers to as an 'objective correlative.' This means that when two things are put side by side such that they coexist, we tend not to question whether or not this makes sense (Williamson, 1978, p. 29). Therefore, in the consistent pairing of Drinkaware with signs that connote the referent systems of truth and science, the meaning of these systems may be transferred to Drinkaware. The significant point here is the construction of Drinkaware's ethos and its identity as an expert through its campaign materials.

Performing the role of educator. Drinkaware is the 'sender' of the campaign messages, and they are visually recognizable as information and educational campaigns; they follow the format and composition typically used in information campaigns and appear in places that these campaigns would appear, such as on the bus or in a bar. Hence, their identity as a source of information and education is reinforced because they are performing this exact role. This educational role is often performed by public authorities, such as when they provide information about official government guidelines in relation to alcohol consumption. This role is made even more salient in the campaigns in instances where an official government unit guideline label is included and/or when they inform the receiver about the law ('What's the law around alcohol and young people?'). The performance of the role of educator and the signaling of association with the law and official government guidelines suggest authority and 
proximity to the official authority, namely the government, and signals governmental approval of the campaign material.

\section{Discussion and conclusion}

Recent work in the field of organizational studies (e.g. Bell et al., 2014; Meyer et al., 2013) has emphasized that visuals are widely used by organizations, both internally and in relation to different audiences and stakeholders. Visuals have also been identified as being exceptionally useful framing devices due to their ability to abstruse issues and appear overtly factual (Rodriguez \& Dimitrova, 2011; Wischmann, 1987). Yet, the previous literature on framing in issue fields has primarily focused on verbal accounts, and thus far, only limited work has addressed the visual (but see Höllerer et al., 2013; Lefsrud et al., 2018). In addition, work on issue fields (Hoffman, 1999) has often addressed struggles and contestation (e.g. framing contests; Kaplan, 2008) in fields (Guérard et al., 2013; Lefsrud \& Meyer, 2012; Meyer \& Höllerer, 2010). Limited work has addressed how certain visual framing efforts may also contribute to establishing a collective organization's identity as an expert within an issue field. Because visual framing efforts may have an important role to play in this regard, it is important to explore how visuals contribute. Existing research and my previous work have motivated the research question addressed here: How do visuals contribute to framing an issue and establishing a collective organization as an expert within an issue field? 
To address the research question, I studied the case of the IBIC, Drinkaware, and its visual framing of the issue of alcohol-related harm in its campaign material. I examined the various framing functions performed by the campaigns, that is, normalizing alcohol consumption, defining and delimiting the scope the issue and the responsible parties, and establishing the organization's identity as an expert. Each function had several components. First, the main rhetoric in the campaign was centered on normalizing alcohol consumption; the foundational visual framing components were normalizing and contrasting, which served to construct the distinction between normal responsible drinking and irresponsible drinking. Second, the function of defining and delimiting the issue and responsible parties (causal and political) was rooted in subject appellation, contrasting, and moralization and emotional activation. Finally, establishing identity as an expert relied on the consistent association of signs (signs of truth and science) and performing the role, in this case, that of educators.

Through its campaigns, Drinkaware is framing the issue of alcohol-related harm as a problem of irresponsible drinking. Individual consumers and parents have the primary responsibility to solve and prevent the problem (causal and political responsibility). The campaign pieces draw on a wider logic of liberal democracy in which people are free agents capable of making the 'right' decisions, given that they have access to complete and accurate information (the truth). In the campaigns, this is marked by the depiction of the subject (the receiver) as an individual and a free agent; 
this is also common in the subject appeal of regular advertising (Williamson, 1978). It is particularly salient in all the signaling of contrasts (being responsible versus irresponsible) as a matter of conscious choice, in which all possible positive and negative outcomes (consequences) are portrayed as evident to the subject at any given time and place. From this standpoint, the importance of information is crucial and linked to the proposal of carefully constructed campaigns targeted at specific groups of people. In this regard, it is worth considering alternative definitions and explanations for the issue that are 'invisible' in (excluded from) Drinkaware's materials, such as drinking during pregnancy, alcoholism, and perhaps even the industry's reach in terms of advertising (i.e. potentially addressing youngsters) or the availability of alcohol (how easily children may access alcohol).

Drinkaware's issue framing differs from other framings put forward by other organizations in the issue field, such as the WHO and the Global Alcohol Policy Alliance (GAPA), which argue that the wider public, and especially some groups of people such as children and young people, are not necessarily free agents capable of making 'good' decisions that affect their health in the long term. Instead, these organizations push for tighter legislation and higher taxes on alcohol products, arguing that these are the only measures that will lead to behavioral change. In the campaign material, Drinkaware's framing of the issue is focalized on consumers' irresponsible drinking and education, a framing that excludes invisible alternative explanations and 
simultaneously constructs an 'image' of a socially responsible alcohol industry, which funds the organization and supports its information campaigns. In this regard, the construction of Drinkaware's identity as an expert is essential, as it lends credibility to its specific framing of the issue.

Based on the findings described in the article, this study makes three central contributions. First, it contributes to organizational theory and institutional theory by elaborating on the visual framing functions performed by an organization's campaign material. Previous work that has empirically studied the role of visuals in institutionalization processes (e.g. Delmestri, Oberg and Drori, 2015; Höllerer et al., 2013; Lefsrud et al., 2018) has shown that visuals may be used to bridge ideational differences as well as in the translation of global contexts (Höllerer et al., 2013). Interestingly, this study showed that visuals can also be used to construct contrasts, such as between responsible and irresponsible drinking. The framing function component of contrasting is particularly salient in the Drinkaware campaigns. In this regard, it is worth noting that cultural studies on alcohol have suggested that 'a proper and improper use of alcohol is socially defined and transmitted in almost every society' (Gusfield, 1986, p. 25). Influencing the general public's understanding of alcohol consumption and establishing the contrast between responsible and irresponsible drinking may be crucial in reframing the issue from being a problem of the product (and the industry) or 
regulators (government) to a problem that is the responsibility of the consumers (and their parents).

While the study clearly showed that the visuals contribute to the framing of the issue, it did not provide insights into the inner workings of the collective organization; thus, we do not know how and to what degree the visual framing efforts contributed to the mobilization of allies and support for Drinkaware. An interesting future study could explore this link further, investigating the factors that mobilize organizations to support or join a collective organization, focusing explicitly on the role of visuals.

Second, and relatedly, the study contributes to the literature on issue fields by showing how the issue was defined and delimited in visuals through the subject (depiction and interaction with specific groups, namely excessive drinkers, young people, and parents). Subjects were invited to identify with the message using visual cues - that is, young people, bright colors, and humorous messages. The specific emotional appeal of visuals has been highlighted by others (e.g. Doerr et al., 2013; Snow et al., 2014). My findings extend this research by clarifying the component of moralization and emotional activation, doing what is right (i.e. for a good parent), and the use of humor and/or fear of being in the out-group or a bad parent. In addition, the findings specify how this emotional appeal may be used in the visual framing of issues, thereby elaborating on one of the ways that responsibility for public issues (causal and 
political) may get pushed onto individuals through visual framing and its strong emotional appeal.

A limitation of this study is that it does not show how the subjects-audiences for the individual campaigns - received the message, as the material was coded and analyzed by the author. An interesting future research direction could be to explore how far and in what ways the visual framing of issues might actually influence the target audience through various visual cues.

Finally, the findings show how visual framing contributed to establishing Drinkaware's identity as an expert in an issue field. Lefsrud and Meyer (2012) show how professionals' framing efforts construct an issue (climate change) and themselves as experts in an issue field. Here, I complement their work by illustrating how the visual dimension contributed to establishing a collective organization as an expert. Studying visuals used in corporate social responsibility reports, Höllerer et al. (2013) demonstrate how visuals can be used to overcome 'credibility gaps' through authorization, a form of legitimation that is achieved by establishing an association with authority, for example, law or government. This is comparable to my observations in relation to the consistent association with signs of truth and science. I contribute to this line of work by showing how visuals may serve to establish a collective organization as an expert in an issue field through the visual-framing functions outlined in the article, and significantly, via 
the consistent association of signs (truth and science) and being the 'sender' behind the campaign message, and thus, performing the role.

This study focused on an organization's construction of an identity as an expert in its campaign material, and it did not consider whether stakeholders (e.g. consumers, media, and government) and other actors in the issue field (e.g. other alcohol organizations and collaborative partners) perceived Drinkaware as an expert in alcohol education. By considering other actors within an issue field, future studies could explore how an organization's visual framing efforts may contribute to its positioning in relation to an issue. On this topic, it would be particularly interesting to explore whether and how visual framing may enable collective organizations to attain a powerful position in a field (Fligstein \& McAdam, 2011; Gamson, 1988).

Visuals and visual framing efforts represent important dimensions in organizations' attempts to influence and shape issue fields, but they are also significant parts of their external environment in a more general sense. Visuals are constructed in the organizational environment, and then they are processed, mediated, transformed, or challenged by organizational audiences (both internal and external). Still, visuals and especially visual framing are still underexplored areas in organizational studies. This article showed how to systematically explore the use of visuals in issue framing. The study of visuals complements our existing approaches in organizational theory in an important way and may allow us to explore different aspects of meaning construction. 


\section{Notes}

\footnotetext{
${ }^{1}$ Alcohol-related harm has always been an issue (i.e. the temperance movement), but this new wave of concern emerged in the 1970s and increased in salience throughout the 1990s and 2000s.

${ }^{2}$ Drinkaware is funded by donations from the alcohol industry, which is made up of $8.8 \%$ on trade (bars and restaurants), $34.8 \%$ off trade (retail supermarkets), $55.7 \%$ producers, and $0.6 \%$ wholesalers.
} 


\section{References}

Ahrne, G., \& Brunsson, N. (2005). Organizations and meta-organizations. Scandinavian Journal of Management, 21(4), 429-449.

Aristotle (1984). The rhetoric and poetics of Aristotle Modern Library College Editions.

Babor, T. F., \& Robaina, K. (2013). Public health, academic medicine, and the alcohol industry's corporate social responsibility activities. American Journal of Public Health, 103(2): 206-214.

Bell, P. (2001). Content analysis of visual images. In T. Leeuwen \& C. Jewitt (Eds.), Handbook of visual analysis. Thousand Oaks, CA: Sage Publications, 92-118

Bell, E., Warren, S., \& Schroeder, J. (Eds.). (2014). The Routledge companion to visual organization. Oxon/New York: Routledge.

Benford, R. D., \& Snow, D. A. (2000). Framing Processes and social movements: An overview and assessment. Annual Review of Sociology, 26(1), 611-639.

Campbell, J. L. (1989). Corporations, collective organization, and the state: Industry response to the accident at Three Mile Island. Social Science Quarterly, 70(3), 650-666.

Christiansen, L., H., \& Kroezen, J., J. (2016). Institutional maintenance through business collective action: The alcohol industry's engagement with the issue of alcohol-related harm. In Gehman, J., Lounsbury, M., Greenwood, R. (Eds), Research in the Sociology of Organizations (How institutions matter!) 48(B), 101-143.

Christiansen, L., H., \& Lounsbury, M. (2013). Strange brew: Bridging logics via institutional bricolage and the reconstitution of organizational identity. In Lounsbury M. \& Boxenbaum E. (Eds.), Research in the Sociology of Organizations (Institutional Logics in Action) 39(B), 509-542.

Cooper, B. (2010). Focus - message on a bottle: How drinkaware is helping alcohol education. Retrieved April 16th, 2014, from http://www.just-drinks.com/analysis/how-drinkaware-is-helping-alcoholeducation id101512.aspx

Cornelissen, J. P., \& Werner, M. D. (2014). Putting framing in perspective: A review of framing and frame analysis across the management and organizational literature. The Academy of Management Annals, 8(1), 181-235.

Delmestri, G., Oberg, A., \& Drori, G. S. (2015). The unbearable lightness of university branding. International Studies of Management \& Organization, 45(2), 121-136.

Doerr, N., Mattoni, A., \& Teune, S. (2013). Toward a visual analysis of social movements, conflict, and political mobilization. Emerald Group Publishing Limited, xi-xxvi. 
Doerr, N., \& Teune, S. (2012). The imagery of power facing the power of imagery. Towards a visual analysis of social movements. In Fahlenbrach, K., Klimke, M., Scharloth, J., \& Wong, L. (Eds.), The 'establishment' responds: Power, politics and protest since 1945. London: Palgrave, 43-55.

Drinkaware (2007) What we do. Drinkaware trust, retrieved December 27. 2007 http://www.drinkawaretrust.org.uk/what-we-do.html. Retrieved via http://web.archive.org.

Edelman, M. (1988). Constructing the political spectacle. Chicago: The University of Chicago Press.

Eisenhardt, K. M. (1989). Building theories from case study research. Academy of Management Review, $14(4), 532-550$.

Fligstein, N. \& McAdam, D. (2011) A theory of fields. New York: Oxford University Press

Gamson, W. A., Croteau, D., Hoynes, W., \& Sasson, T. (1992). Media images and the social construction of reality. Annual Review of Sociology, 18, 373-393.

Gamson, W . A . (1988) Political discourse and collective action. In B. Klandermans et al ed., From Structure to Action: Comparing Social Movement Research across Cultures, Greenwich, Conn: JAI, 219-44.

Gamson, W. A., \& Modigliani, A. (1989). Media discourse and public opinion on nuclear power: A constructionist approach. American Journal of Sociology, 95(1), 1-37

Goffman, E. (1974). Frame analysis: An essay on the organization of experience. Cambridge: Harvard University Press.

Goldstein, G., Goon, E., \& Yach, D. (1995). New public health and WHO's ninth general program of work, A discussion paper. Geneva, Switzerland: World Health Organization, Division of Human Resources for Health.

Guérard, S., Bode, C., \& Gustafsson, R. (2013). Turning point mechanisms in a dualistic process model of institutional emergence: The case of the diesel particulate filter in Germany. Organization Studies, 34(5-6), 781-822.

Gusfield, J. (1981). The culture of public problems, drink-driving and the symbolic order. Chicago: The University of Chicago Press.

Gusfield, J. (1986) Symbolic crusade, status politics and the American Temperance Movement. $2^{\text {nd }}$ edition, Chicago, University of Illinois Press

Hoffman, A. J. (1999). Institutional evolution and change: Environmentalism and the U.S. chemical industry. The Academy of Management Journal, 42(4), 351-371. 
Höllerer, M. A., Jancsary, D., Meyer, R. E., \& Vettori, O. (2013). Imageries of corporate social responsibility: Visual recontextualization and field-level meaning. In Lounsbury M. \& Boxenbaum E. (Eds.), Research in the Sociology of Organizations (Institutional Logics in Action), 39(B), 139174.

Jancsary, D., Höllerer, M. A., \& Meyer, R. E. (2015). Critical Analysis of Visual and Multimodal Texts. Critical Analysis of Visual and Multimodal Texts. Los Angeles: SAGE Publications, 180-204.

Jasper, J. M., \& Poulsen, J. D. (1995). Recruiting strangers and friends: Moral schocks and social networks in animal rights and anti-nuclear protests. Social Problems, 42(4), 493-511.

Jones, C., Meyer, R., Jancsary, D., \& Höllerer, M. (2017). The material and visual basis of institutions. In R. Greenwood, C. Oliver, T. Lawrence, \& R. E. Meyer (Eds.), The SAGE Handbook of Organizational Institutionalism. (2 ed.). SAGE.

Kaplan, S. (2008). Framing contests: Strategy making under uncertainty. Organization Science, 19(5),

Kress, G., \& van Leeuwen, T. (1996). Reading images - the grammar of visual design. London: Routledge.

Lefsrud, L. M., Graves, H., \& Phillips, N. (2018). Dirty oil or ethical oil? Visual rhetoric in legitimation struggles. Research in the Sociology of Organizations, 54(B), 127-168

Lefsrud, L. M., \& Meyer, R. E. (2012). Science or science fiction? professionals' discursive construction of climate change. Organization Studies, 33(11), 1477-1506

Litrico, J.-B., \& David, R. J. (2017). The evolution of issue interpretation within organizational fields: Actor positions, framing trajectories, and field settlement. Academy of Management Journal, 60(3), 986-1015

Luhtakallio, E. (2013). Bodies keying politics: A visual frame analysis of gendered local activism in France and Finland. In N. Doerr, A. Mattoni \& S. Teune (Eds.), Advances in the visual analysis of social movements (research in social movements, conflicts and change, volume 35) Emerald Group Publishing Limited, 27-54

McLaren, K. (2013). The emotional imperative of the visual: Images of the fetus in contemporary Australian pro-life politics. Emerald Group Publishing Limited, 81-103.

Messaris, P. and L. Abraham ( 2001) 'The Role of Images in Framing News Stories', in S. Reese et al. (eds) Framing Public Life, 215-26

Meyer, R. E., Höllerer, M. A., Jancsary, D., \& van Leeuwen, T. (2013). The visual dimension in organizing, organization, and organization research: Core ideas, current developments, and promising avenues. Academy of Management Annals, 7(1), 489-555. 
Meyer, R. E., \& Höllerer, M. A. (2010). Meaning structures in a contested issue field: A topographic map of shareholder value in austria. Academy of Management Journal, 53(6), 1241-1262.

Rodriguez, L., \& Dimitrova, D. V. (2011). The levels of visual framing. Journal of Visual Literacy, $30(1), 48-65$.

Snow, D. A., \& Benford, R. D. (1988). Ideology, frame resonance, and participant mobilization. International Social Movement Research, 1, 197-218.

Snow, D. A., Rochford, E. B.,Jr., Worden, S. K., \& Benford, R. D. (1986). Frame alignment processes, micromobilization, and movement participation. American Sociological Review, 51(4), 464-481.

Snow, D., Benford, R., McCammon, H., Hewitt, L., \& Fitzgerald, S. (2014). The emergence, development, and future of the framing perspective: $25+$ years since "frame alignment". Mobilization: An International Quarterly, 19(1), 23-46.

Suddaby, Roy, \& Greenwood, Royston (2005). Rhetorical strategies of legitimacy. Administrative Science Quarterly, 50, 35-67.

Tulchinsky, T., \& Varavikova, E. (2010). What is the "new public health"? Public Health Reviews, 32(1), $25-53$

Williamson, J. (1978/2010). Decoding advertisements, ideology and meaning in advertising. London: Marion Boyars Publishers Ltd.

Wischmann, L. (1987). Dying on the front page: Kent state and the Pulitzer prize. Journal of Mass Media Ethics, 2(2), 67-74.

World Health Organization. (2014). Global status report on alcohol and health 2014. Retrieved from http://www.who.int/substance_abuse/publications/global_alcohol_report/en/27th of March, 2014

World Wide Brewing Alliance. Global Corporate Social Responsibility Initiatives - Social Aspects Organizations and Other Organizations Supported by the Industry., Retrieved 27th of March, 2014 (http://gsri.worldwidebrewingalliance.org/php/initiatives/list.php?year=All\&num=20\&type_id=13\& country $=$ \&ini_status $=\&$ company $=$ ). 
Figure 1 - Illustration of the increased pairing of alcohol and health in five top UK newspapers

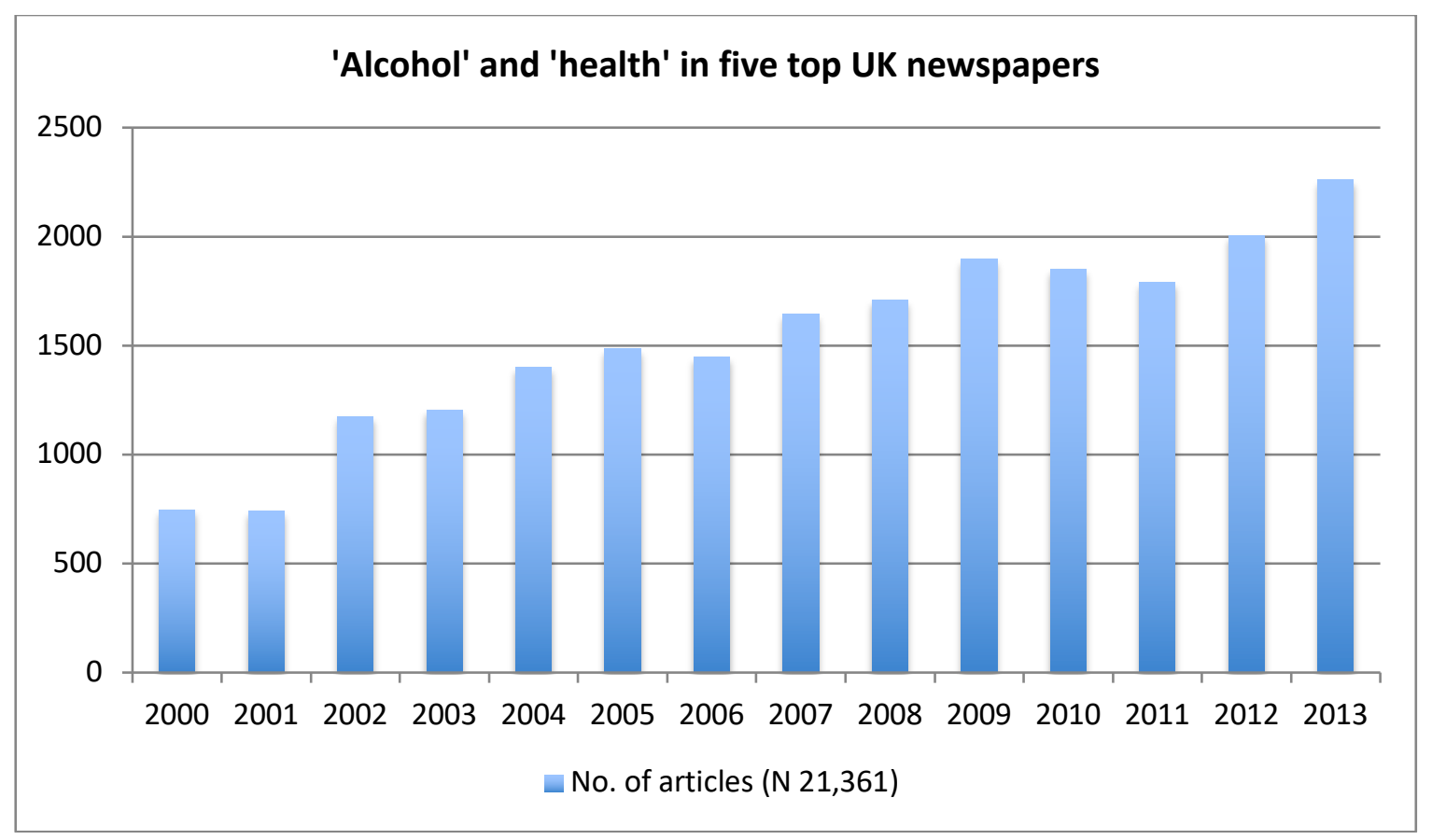

Illustration notes:

Based on a search in the database Newsbank, Figurel provides an illustration of the keyword pairing of 'health' and 'alcohol' in articles from five top UK newspapers from 2000 to 2013 -Daily Mirror/Sunday Mirror, The Guardian, the Times, the Sun and Daily Telegraph/The Sunday Telegraph.

Number of articles by year: 2000 (747), 2001 (741), 2002 (1175), 2003 (1204), 2004 (1402), 2005 (1486), 2006 (1449), 2007 (1645), 2008 (1710), 2009 (1897), 2010 (1849), 2011 (1791), 2012 (2005), 2013 (2260). 
Table 1 - Main data sources on Drinkaware

Campaign material from the following campaigns:

- 'The Drinkaware Challenge' (2007)

- 'Truth about Booze' (2007)

- 'How much is too much?' (2008)

- 'Christmas survival guid'e (2008)

- 'Tips for a Christmas to remember' (2008)

- 'Why let the good times go bad?' part 1 (2009) + co-branding

- 'Why let the good times go bad?' part 2 (2010) + co-branding

- 'Why let the good times go bad?' part 3 (2011)

- 'Why let the good times go bad?' Mobile Application (2011)

- 'In:tuition-inspiring Positive Choices' (2012)

- 'Your kids and alcoho'l (2012)

- 'Mumtank' (2012)

- 'Talk now and avoid problems later' (2013)

- 'Because it's Monday... '(2013/2014) 


\begin{tabular}{|c|c|}
\hline \multicolumn{2}{|c|}{$\begin{array}{l}\text { Table } 2 \text { - Overview of the methodological approach and the terminology/definitions used for coding } \\
\text { the campaign pieces (visual and verbal modes) } \\
\text { INDIVIDUAL SINGLE PIECE CODING (step 1) }\end{array}$} \\
\hline Coding-type & Definition \\
\hline Description & Detailed description of the content of the campaign piece (verbal and visual) \\
\hline Condensing symbols & $\begin{array}{l}\text { Visual and verbal elements that capture, both cognitively and emotionally, a range } \\
\text { of meanings and convey a particular framing. A powerful symbol lends credibility } \\
\text { to an explicit argument by drawing on implicit assumption and 'common sense.' } \\
\text { These symbols may even signal a moral absolute that is unquestionable (Jasper } \\
\text { and Paulsen, 1995, p. 498). }\end{array}$ \\
\hline Colors & $\begin{array}{l}\text { Certain colors might carry certain meanings and different color saturations might } \\
\text { also function as modality markers to symbolize varying degrees of 'credibility' } \\
\text { value: for example, the visual depiction of 'what is' (reality) or 'what could be' } \\
\text { (fantasy or ideal) (Kress and van Leeuwen, 1996, pp. 159-180; Williamson, } \\
\text { 1978). }\end{array}$ \\
\hline Subject; Appellation & $\begin{array}{l}\text { 'Totemism' - the subject as signified. We (subjects) are created as a particular } \\
\text { type of subject by the products and messages in advertisements (Levi-Strauss, } \\
\text { 1973; Williamson, 1978, pp. 45-50). }\end{array}$ \\
\hline Composition & $\begin{array}{l}\text { The composition of the visual as a whole (multimodal text); the way in which the } \\
\text { representational and interactive elements are made to relate to one another to } \\
\text { create a meaningful whole (Kress and van Leeuwen, 1996, p. 181). }\end{array}$ \\
\hline $\begin{array}{l}\text { Differentiation } \\
\text { (contrasting) }\end{array}$ & $\begin{array}{l}\text { Differentiation and contrasting is typically used in advertising to create a } \\
\text { difference between a product and others in its category (Williamson, 1978). }\end{array}$ \\
\hline Absence & $\begin{array}{l}\text { In hermeneutics, meaning is always absent, as meaning does not reside in things. } \\
\text { However, this is even more significant when there is an absence in the signifying } \\
\text { surface (e.g. an absent person or product); the receiver is invited to participate in } \\
\text { a 'discovery of meaning' and to fill the absence (Williamson, 1978, pp. 76-77). }\end{array}$ \\
\hline Modes of Argument & $\begin{array}{l}\text { Ethos: Ethical appeal, establishing a credible source. } \\
\text { Pathos: Emotional appeal, persuasion via emotions. } \\
\text { Logos: Logical appeal, use of logical reasoning (Aristotle, 1984). }\end{array}$ \\
\hline & $\begin{array}{l}\text { INDIVIDUAL SINGLE PIECE CODING (step 2) } \\
\text { Framing of the issue (broader context) }\end{array}$ \\
\hline $\begin{array}{l}\text {-What is alcohol and } v \\
\text { that go together and hi } \\
\text { 1974: 21). }\end{array}$ & $\begin{array}{l}\text { role does it have in society? (Main rhetoric), packages of proposals and critique } \\
\text { sht certain aspects of a particular issue. 'A schemata of interpretation' (Goffman, }\end{array}$ \\
\hline -Who is responsible & issue? (causal responsibility) \\
\hline -How should it be tack & nd by whom? (political responsibility) \\
\hline & $\begin{array}{l}\text { CODING ACROSS CAMPAIGN PIECES (step 3) } \\
\text { Framing of the issue (broader context) }\end{array}$ \\
\hline Comparing and cont & the different campaign pieces to establish common themes \\
\hline $\begin{array}{l}\text { f the visual } \\
\text { the issue? }\end{array}$ & (Goals and Proposals) - What function does the visual mode ha \\
\hline
\end{tabular}




\begin{tabular}{|c|c|c|c|c|c|c|}
\hline \multirow{2}{*}{$\begin{array}{l}\begin{array}{l}\text { Framing } \\
\text { function }\end{array} \\
\text { Themes } \\
\text { in campaigns }\end{array}$} & \multirow{2}{*}{$\begin{array}{l}\text { Normalizing alcohol } \\
\text { consumption }\end{array}$} & \multicolumn{3}{|c|}{ Defining and delimiting the issue and the responsible parties } & \multicolumn{2}{|c|}{ Establishing identity as an expert } \\
\hline & & $\begin{array}{l}\text { Excessive drinking } \\
\text { problem }\end{array}$ & Youth problem & Parenting problem & $\begin{array}{l}\text { Consistent association } \\
\text { of signs of 'truth and } \\
\text { science' }\end{array}$ & $\begin{array}{l}\text { Performing the role of } \\
\text { educator }\end{array}$ \\
\hline $\begin{array}{l}\text { Number of } \\
\text { campaign pieces } \\
\text { including } \\
\text { themes (N 52) } \\
\end{array}$ & $(\mathrm{N} 45)$ & ( N 25) & $(\mathrm{N} 40)$ & $(\mathrm{N} 11)$ & $(\mathrm{N} 35)$ & $(\mathrm{N} 41)$ \\
\hline $\begin{array}{l}\text { Theme } \\
\text { assumptions }\end{array}$ & $\begin{array}{l}\text { Alcohol is a normal } \\
\text { and institutionalized } \\
\text { part of social life. Only } \\
\text { a minority of people } \\
\text { drink irresponsibly. }\end{array}$ & $\begin{array}{l}\text { There are a few } \\
\text { people (often young } \\
\text { people) and a few } \\
\text { occasions, for } \\
\text { example, Christmas, } \\
\text { football, or partying, } \\
\text { where some people } \\
\text { drink irresponsibly. }\end{array}$ & $\begin{array}{l}\text { The alcohol debut } \\
\text { age is too low, and } \\
\text { youth drinking is a } \\
\text { fairly widespread } \\
\text { phenomenon. }\end{array}$ & $\begin{array}{l}\text { Some parents do not } \\
\text { know how to talk to } \\
\text { their children about } \\
\text { alcohol, thus, some } \\
\text { children and young } \\
\text { people drink } \\
\text { irresponsibly. }\end{array}$ & $\begin{array}{l}\text { There is a truth about } \\
\text { alcohol, but not } \\
\text { everyone has access to } \\
\text { information (lack of } \\
\text { awareness). }\end{array}$ & $\begin{array}{l}\text { Consumers lack the } \\
\text { knowledge to make an } \\
\text { informed decision. }\end{array}$ \\
\hline $\begin{array}{l}\text { Modes of } \\
\text { argument: } \\
\text { Ethos }\end{array}$ & $\begin{array}{l}\text { Confirming the } \\
\text { audience belief that the } \\
\text { consumption of } \\
\text { alcohol is normal } \\
\text { (ethically right) }\end{array}$ & $\begin{array}{l}\text { Campaigns are non- } \\
\text { judgmental and } \\
\text { provide advice or } \\
\text { guidance like a } \\
\text { friend. }\end{array}$ & $\begin{array}{l}\text { Campaigns use } \\
\text { informal verbal and } \\
\text { visual language } \\
\text { appropriate for a } \\
\text { young audience. }\end{array}$ & $\begin{array}{l}\text { Recommendations } \\
\text { are based on } \\
\text { research/the facts. } \\
\text { Parents talking to } \\
\text { their children about } \\
\text { alcohol is just as } \\
\text { basic as parents } \\
\text { talking to their } \\
\text { children about sex. }\end{array}$ & $\begin{array}{l}\text { Education and } \\
\text { information is based on } \\
\text { 'truth and science'. }\end{array}$ & $\begin{array}{l}\text { Build by association to } \\
\text { information (facts). } \\
\text { Visuals (and language) } \\
\text { are relevant to the target } \\
\text { audience. }\end{array}$ \\
\hline $\begin{array}{l}\text { Mode of } \\
\text { argument: } \\
\text { Pathos }\end{array}$ & $\begin{array}{l}\text { Arguing that it is } \\
\text { normal to drink or that } \\
\text { drinking too much (or } \\
\text { not drinking) might } \\
\text { lead to social } \\
\text { exclusion. }\end{array}$ & $\begin{array}{l}\text { Appeal to emotions } \\
\text { of remembering the } \\
\text { 'good times' and } \\
\text { being part of the fun } \\
\text { or feeling sick } \\
\text { and/or being } \\
\text { excluded from the } \\
\text { fun. }\end{array}$ & $\begin{array}{l}\text { Appeal to emotions } \\
\text { of success, failure, } \\
\text { and the feeling of } \\
\text { being included in or } \\
\text { excluded from a } \\
\text { community. }\end{array}$ & $\begin{array}{l}\text { Arguing that their } \\
\text { lack of action will } \\
\text { harm their children } \\
\text { (e.g. they could end } \\
\text { up in the emergency } \\
\text { department [A\&E] } \\
\text { or get in trouble). }\end{array}$ & $\begin{array}{l}\text { Following the } \\
\text { truth/fact/science will } \\
\text { keep the consumer safe } \\
\text { from any health risks. }\end{array}$ & $\begin{array}{l}\text { Not following } \\
\text { information/education } \\
\text { will make the consumer } \\
\text { or their loved ones (i.e. } \\
\text { children, friends) } \\
\text { vulnerable and/or sick. }\end{array}$ \\
\hline
\end{tabular}




\begin{tabular}{|c|c|c|c|c|c|c|}
\hline $\begin{array}{l}\text { Mode of } \\
\text { argument: } \\
\text { Logos }\end{array}$ & $\begin{array}{l}\text { Alcohol consumption } \\
\text { has always been the } \\
\text { norm (e.g. 'since } \\
10,000 \text { BC', Figure } 2) \text {. }\end{array}$ & $\begin{array}{l}\text { Giving advice that } \\
\text { will help consumers } \\
\text { to not drink to } \\
\text { excess (e.g. eat and } \\
\text { drink water). }\end{array}$ & $\begin{array}{l}\text { Giving advice that is } \\
\text { useful when } \\
\text { consumers have less } \\
\text { knowledge and } \\
\text { experience with } \\
\text { alcohol and } \\
\text { drinking. }\end{array}$ & $\begin{array}{l}\text { Arguing using } \\
\text { research/'facts' that } \\
\text { children's/young } \\
\text { people's alcohol } \\
\text { behavior is the } \\
\text { parents' } \\
\text { responsibility }\end{array}$ & $\begin{array}{l}\text { 'Everybody knows'- } \\
\text { that we should let our } \\
\text { (alcohol)behavior be } \\
\text { informed by 'truth and } \\
\text { science'. }\end{array}$ & $\begin{array}{l}\text { Follow the experts' } \\
\text { guidelines. }\end{array}$ \\
\hline $\begin{array}{l}\text { Key role of the } \\
\text { visual mode } \\
\text { examples } \\
\text { (see also Figure } \\
\text { 2) }\end{array}$ & $\begin{array}{l}\text { Normalizing: } \\
\text {-Invoking traditional } \\
\text { drinking occasions } \\
\text { (e.g. Christmas, } \\
\text { parties, when relaxing } \\
\text { on the couch) and } \\
\text { traditions of drinking. } \\
\text {-Settings are average } \\
\text { homes (e.g. homes } \\
\text { appear to be average } \\
\text { middle class homes). } \\
\text { - Recycling bucket in a } \\
\text { plain neighborhood). } \\
\text {-Depictions of } \\
\text { average, 'normal' } \\
\text { people, not models. } \\
\text { - Contrasting: 'Get } \\
\text { watered not } \\
\text { slaughtered' (text), and } \\
\text { in composition-two } \\
\text { pictures divided by a } \\
\text { silhouette of a wine } \\
\text { glass or a beer bottle. }\end{array}$ & $\begin{array}{l}\text { Subject: Excessive } \\
\text { drinkers } \\
\text {-Many bottles and } \\
\text { empty glasses } \\
\text { (traces of heavy } \\
\text { drinking) } \\
\text { - People sick or } \\
\text { passed out. }\end{array}$ & $\begin{array}{l}\text { Subject: Young } \\
\text { people who are } \\
\text { passed out, sick, or } \\
\text { alone/left out. } \\
\text {-Composition } \\
\text { distinguishing } \\
\text { success from failure } \\
\text { (left and right), } \\
\text { smiling, happy } \\
\text { young people on the } \\
\text { left and sick people } \\
\text { on the right. } \\
\text {-Bright colors } \\
\text { supporting } \\
\text { humorous messages. } \\
\text {-Creative visual of } \\
\text { pilot hat } \\
\text { (symbolizing a wing } \\
\text { man). }\end{array}$ & $\begin{array}{l}\text { Subject: Parents } \\
\text {-Pictures of parents } \\
\text { drinking in front of } \\
\text { their children. } \\
\text {-Pictures of happy } \\
\text { parents and a teen } \\
\text { looking } \\
\text { skeptical/critical } \\
\text { (sign of a teenager). } \\
\text {-Black color/death } \\
\text { and or bad incidents } \\
\text { (serious problems } \\
\text { with alcohol). }\end{array}$ & $\begin{array}{l}\text { Consistent association } \\
\text { signs: } \\
\text {-Association of the } \\
\text { Drinkaware logo and } \\
\text { 'facts.' } \\
\text {-Parenting material } \\
\text { visually conveys } \\
\text { 'facts' through figures, } \\
\text { tables, and charts. }\end{array}$ & $\begin{array}{l}\text { Performing the role of } \\
\text { educator: } \\
\text { - The campaign itself is } \\
\text { educational, and it is } \\
\text { visually recognizable as } \\
\text { such. } \\
\text {-Government guideline } \\
\text { label stating an official } \\
\text { boundary between the } \\
\text { proper and improper } \\
\text { amount of alcohol units } \\
\text { consumed (visual and } \\
\text { text). }\end{array}$ \\
\hline
\end{tabular}




\begin{tabular}{|c|c|c|c|}
\hline Visual framing functions & & Visual framing components & Visual framing components - \\
\hline $\begin{array}{l}\text { Normalizing alcohol } \\
\text { consumption }\end{array}$ & $\begin{array}{l}\text { Main Rhetoric } \\
\text { Alcohol consumption is normal. } \\
\text { Differentiating between proper and improper } \\
\text { use of alcohol (responsible and irresponsible } \\
\text { consumption). }\end{array}$ & $\begin{array}{l}\text { Signifying normal: } \\
\text { Normal drinking occasions such as Christmas } \\
\text { and parties, average homes and neighborhoods } \\
\text { Signifying contrasts: } \\
\text { In composition - two pictures - responsible and } \\
\text { irresponsible - separated by the silhouette of a } \\
\text { wine glass). }\end{array}$ & $\begin{array}{l}\text { Normalizing } \\
\text { Contrasting }\end{array}$ \\
\hline $\begin{array}{l}\text { Defining and delimiting the } \\
\text { scope of the issue and } \\
\text { responsible parties (causal } \\
\text { and political responsibility) }\end{array}$ & $\begin{array}{l}\text { Defining and delimiting through the subject } \\
\text { Consumers/parents } \\
\text { Focus issue areas: } \\
\text { - } \quad \text { Excessive drinking problem } \\
-\quad \text { Youth drinking problem } \\
\text { - } \quad \text { Parenting problem } \\
\text { Issue/problem is solved through education (as } \\
\text { opposed to, for example, legislation) aided and } \\
\text { informed/educated by Drinkaware. }\end{array}$ & $\begin{array}{l}\text { Subject appellation: } \\
\text { Audience addressed (roles and types) i.e. young } \\
\text { people (bright and humorous). Subjects identify } \\
\text { with the message due to visual cues (i.e. parents, } \\
\text { young people, and humor). } \\
\text { Contrasting: } \\
\text { Successful/unsuccessful with the opposite sex, } \\
\text { popular (in-group)/alone or ridiculed (out- } \\
\text { group), feel good/feel sick, good parent/bad } \\
\text { parent, and living room/A\&E (intensive care). } \\
\text { Moralization and emotional activation: } \\
\text { Through humor, morale, fear. }\end{array}$ & $\begin{array}{l}\text { Subject appellation } \\
\text { Contrasting } \\
\text { Moralization and emotional } \\
\text { activation }\end{array}$ \\
\hline $\begin{array}{l}\text { Establishing identity as an } \\
\text { expert }\end{array}$ & $\begin{array}{l}\begin{array}{l}\text { Consistent association with signs } \\
\text { of 'truth and science' }\end{array} \\
\text { Establish the identity of Drinkaware as: } \\
\text { - } \quad \begin{array}{l}\text { Holders and mediators of the 'facts' } \\
\text { (truth and science) about alcohol }\end{array} \\
\text { - } \quad \text { Educators }\end{array}$ & $\begin{array}{l}\text { Consistent association of signs (objective } \\
\text { correlative): } \\
\text { Drinkaware is consistently paired with 'truth and } \\
\text { science.' } \\
\text { Performing the role of educator: } \\
\text { Drinkaware is the 'sender' of the campaign and } \\
\text { is visually recognizable as an information } \\
\text { campaign, building its legitimacy within the } \\
\text { issue fields. }\end{array}$ & $\begin{array}{l}\text { Consistent association of signs } \\
\text { Performing the role }\end{array}$ \\
\hline
\end{tabular}


FIGURE 2

Excessive drinking + alcohol as normal (red circled) examples:
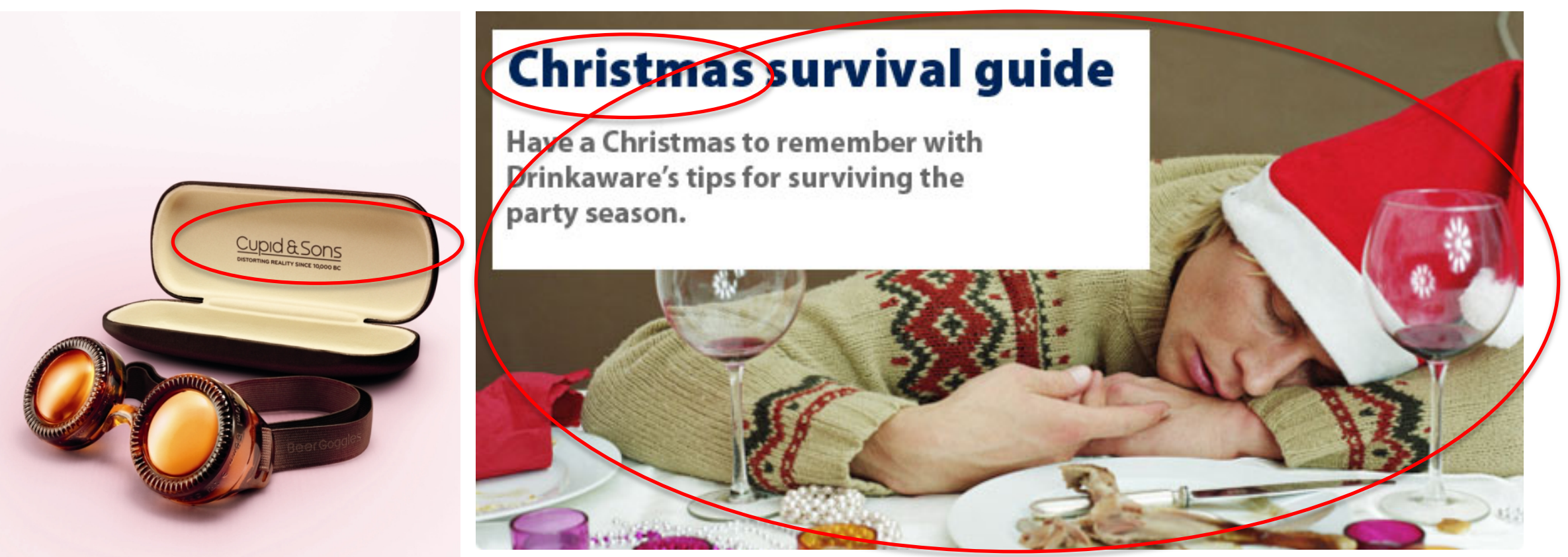

Afraid you'll

pull a moose?

Stay focused by

Left: 'Why let the good times go bad?' part 1, Drinkaware (2009)

pacing your drinks.

Right: Christmas survival guide, Drinkaware (2008) 
FIGURE 2 (continued)

Youth drinking + truth/science (blue circled) examples:
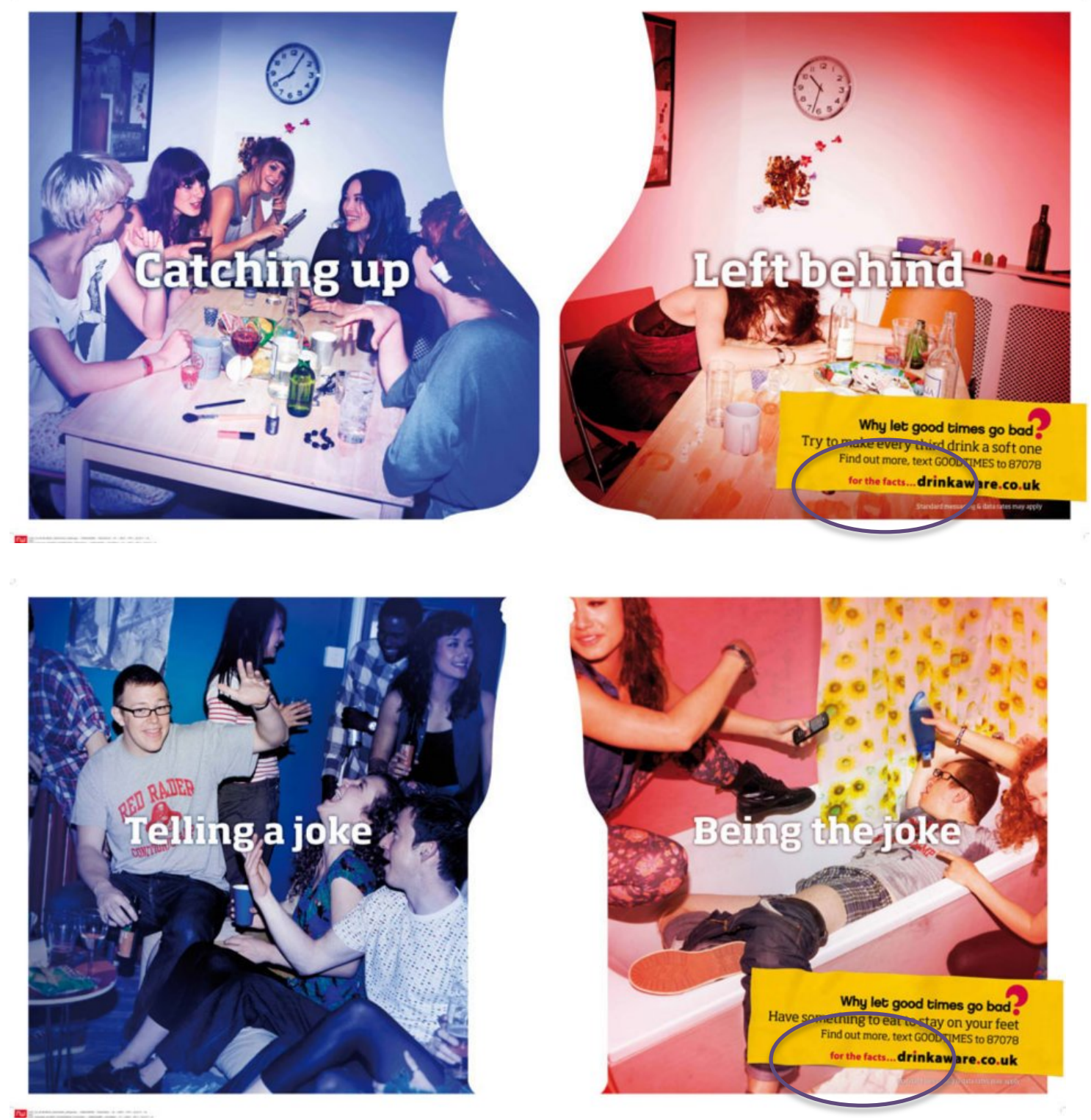

Both pieces: 'Why let the good times go bad?' part 3 (2011) 
FIGURE 2 (continued)

Parenting examples + truth/science (blue circled) + alcohol as normal (red circled) examples:

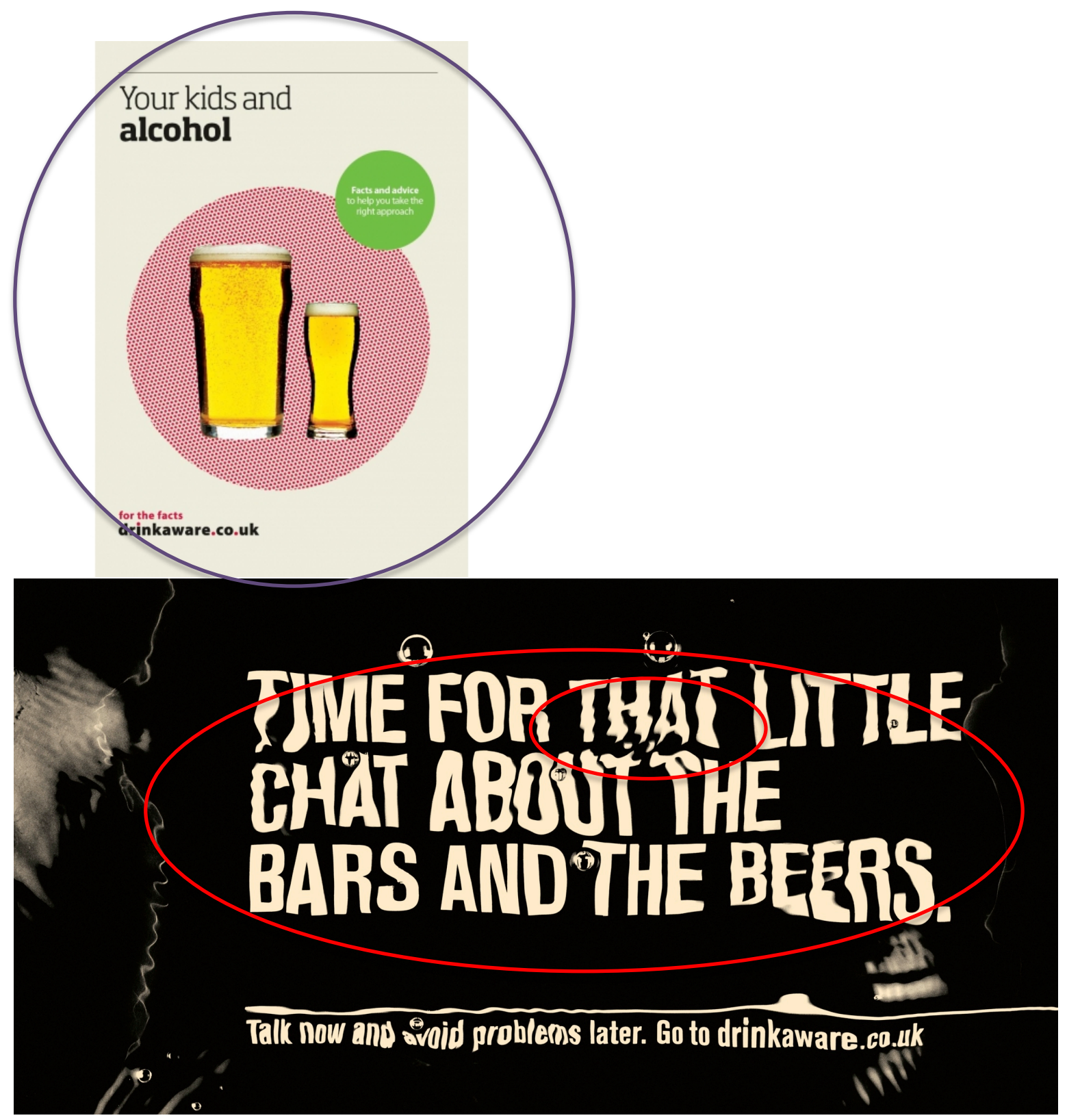

Top: 'Your kids and alcohol,' Drinkaware (2012)

Bottom: 'Talk now and avoid problems later,' Drinkaware (2013) 


\section{Appendix}
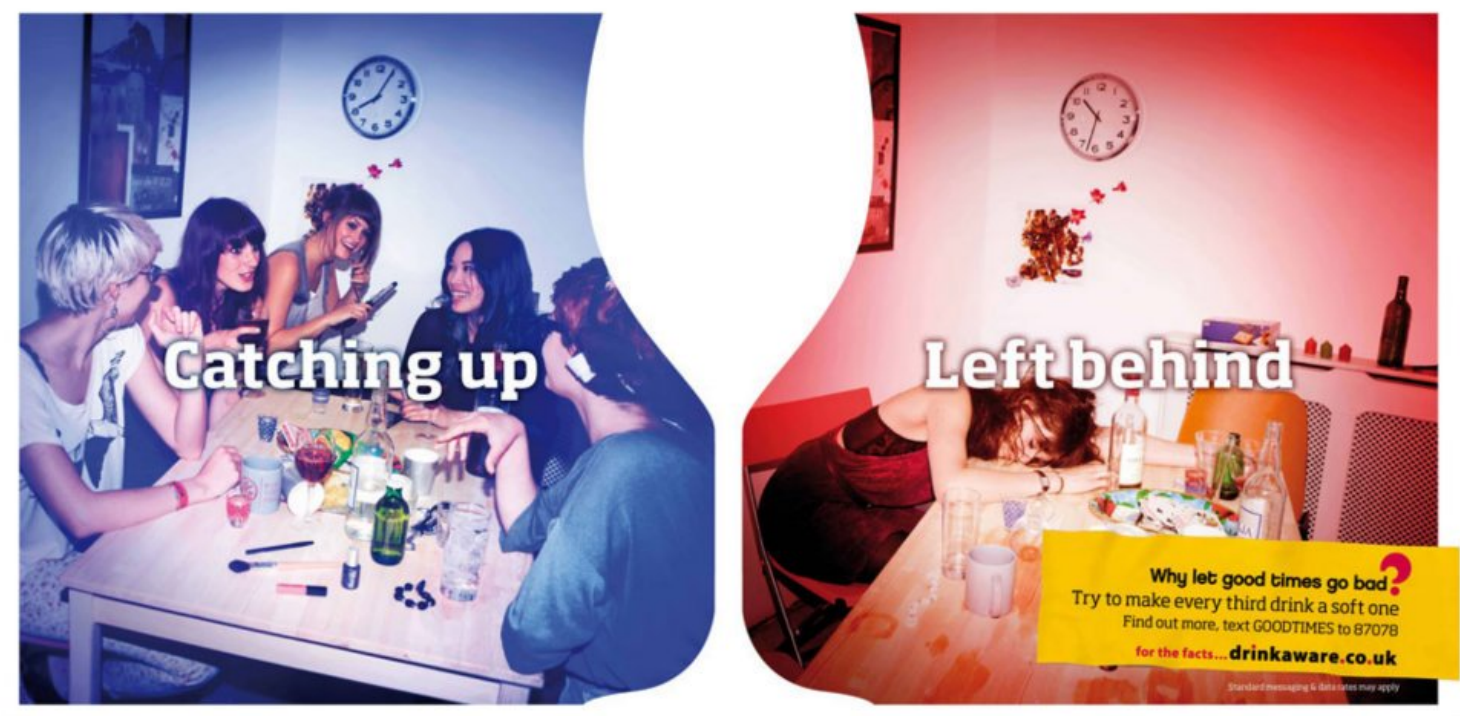

\begin{tabular}{|c|c|}
\hline Coding-type & Visual analysis \\
\hline Description & $\begin{array}{l}\text { Salient pictures on the left and right, with text across, blue color versus red color. } \\
\text { Left-hand picture: Illustrates a group of girls having fun, talking around a table } \\
\text { filled with items such as makeup, a few alcohol containers, and a bag of chips. One } \\
\text { girl in the back is curling her hair as if she is preparing to go out. One girl with dark } \\
\text { hair is the center of attention; everyone is looking at her. She is depicted as being in } \\
\text { the middle of a story-vivid facial expressions and hand signals suggest that she is } \\
\text { making an exciting point or saying something funny, and the other people around } \\
\text { the table are smiling and laughing. There is a clock on the wall in the background } \\
\text { showing } 8 \text { p.m. } \\
\text { Right-hand picture: Shows the exact setting, only now the girl that was previously } \\
\text { (on the left) the center of attention, is now alone, sleeping awkwardly across the } \\
\text { table. Now, the only items on the table are empty glasses and alcohol containers. } \\
\text { The clock on the wall in the background is now showing } 10.00 \text { p.m. } \\
\text { Center of the visual: The silhouette of a wine glass marks the boundary between the } \\
\text { two images. } \\
\text { Right lower corner: Yellow message box with text: 'Why let the good times go } \\
\text { bad?' (bold black letters and a pink question mark in a larger graphic font), the first } \\
\text { part of the logo for the campaign, then 'Try to make every third drink a soft one' } \\
\text { (black letters, smaller font), and 'Find out more, text GOODTIMES to 87078' (next } \\
\text { line, smaller black font). Separate from the other text is the second part of the } \\
\text { campaign logo: 'for the facts...drinkaware.co.uk' (the first part is highlighted in } \\
\text { pink like the question mark, and the second part is in bold black letters with pink } \\
\text { dots). } \\
\text { Text on the right and left: 'Catching up' and 'Left behind' in bold white letters with } \\
\text { a shadow font separating them from the background. }\end{array}$ \\
\hline Composition & $\begin{array}{l}\text { The picture and text on the left signify social success. The picture and text on the } \\
\text { right signify social failure due to excessive drinking. }\end{array}$ \\
\hline
\end{tabular}




\begin{tabular}{|c|c|}
\hline & $\begin{array}{l}\text { The yellow box in the lower right corner is a separate area that presents the solution } \\
\text { to the problem; the key is being the person on the left rather than the one on the } \\
\text { right. This box also represents the sender of the message as an expert on the topic } \\
\text { of staying responsible, providing tools for the subject. Like an advertisement, the } \\
\text { 'tool' to being responsible is the one 'sold' to the receiver of the message. }\end{array}$ \\
\hline $\begin{array}{l}\text { Modes of } \\
\text { Argument }\end{array}$ & $\begin{array}{l}\text { Ethos: The campaign in and of itself is an ethos appeal. Providing such an } \\
\text { 'information' piece signals credibility. So does the text 'for the } \\
\text { facts...drinkaware.co.uk,' connoting the referent system of 'truth and science' } \\
\text { Pathos: Social inclusion (center of attention) on the left, exclusion (alone) on the } \\
\text { right. Exclusion is further emphasized in the text 'Left behind,' anchoring the } \\
\text { intended meaning of the picture in text. } \\
\text { Logos: Logical appeal is mostly evident in the text: 'Try to make every third drink } \\
\text { a soft one,' and 'for the facts...drinkaware.co.uk.' Logical appeal is also evident in } \\
\text { the picture, as the receiver is urged to be the girl on the left rather than the one on } \\
\text { the right. }\end{array}$ \\
\hline $\begin{array}{l}\text { Subject; } \\
\text { Appellation }\end{array}$ & $\begin{array}{l}\text { The subject (the reader of the visual) will most likely be drawn toward the picture } \\
\text { of the popular girl, and might therefore create herself (himself) as such, because of } \\
\text { the visual message. }\end{array}$ \\
\hline $\begin{array}{l}\text { Differentiation } \\
\text { (contrast) }\end{array}$ & $\begin{array}{l}\text { Constructing a contrast between responsible and irresponsible, feeling liked and } \\
\text { feeling alone (left behind). }\end{array}$ \\
\hline Absence & $\begin{array}{l}\text { Absence: The reader has to deduce that the girl in the picture on the right has been } \\
\text { irresponsible in her consumption of alcohol. This absence is also supported } \\
\text { (anchored) by the silhouette of a wine glass. The reader must also deduce that the } \\
\text { girl's friends have left her behind because she was drunk, and thus she is being } \\
\text { 'punished' by social exclusion. }\end{array}$ \\
\hline $\begin{array}{l}\text { Condensing } \\
\text { Symbols }\end{array}$ & $\begin{array}{l}\text { Bottles and the silhouette of a wine glass symbolize drinking. Makeup (on the } \\
\text { table) and hair-styling symbolize the girls having a 'good time' socializing. The } \\
\text { empty room symbolizes that the girl is alone in her suffering (sleeping on the table). }\end{array}$ \\
\hline $\begin{array}{l}\text { Goals and } \\
\text { Proposals }\end{array}$ & $\begin{array}{l}\text { The campaign piece explicitly urges individuals (young people) to act responsibly } \\
\text { when consuming alcohol. 'Try to make every third drink a soft one' and go the } \\
\text { Drinkaware website to get more information on how 'you,' the individual, can be } \\
\text { responsible. In this way, the campaign defines the problem as being the individual's } \\
\text { irresponsible behavior, and suggests that a possible solution is to become } \\
\text { responsible by using their 'tool' (education). }\end{array}$ \\
\hline Framing & $\begin{array}{l}\text { Alcohol is a normal part of social life, but excessive youth drinking should not be } \\
\text { (the problem). Individuals need to take responsibility for their own actions. The } \\
\text { problem of irresponsible alcohol consumption can be solved be the individual's } \\
\text { action and the right information (facts), which is available on the website. }\end{array}$ \\
\hline
\end{tabular}

